\title{
The Effect of Flipped Classroom Through LINE in Teaching English Articles
}

\author{
Munjaroh Dwi Supiani \\ Tajungsari Madrasah Tsanawiyah (MTs), Jawa Timur, Indonesia \\ Jl. Sumatra No. 101 GKB Gresik \\ E-mail: Munjarohdwi07@gmail.com \\ Yudhi Arifani \\ Universitas Muhammadiyah Gresik, Jawa Timur, Indonesia \\ J1. Sumatra No. 101 GKB Gresik \\ E-mail: yudhi_arif@umg.ac.id \\ Candra Hadi Asmana \\ Universitas Muhammadiyah Gresik, Jawa Timur, Indonesia \\ Jl. Sumatra No. 101 GKB Gresik \\ E-mail: candra@umg.ac.id
}

\begin{abstract}
Teaching in English is a worldwide priority, but teaching methodology is not necessarily in line with the changing needs of students. Therefore, this study explores the effects of flipped classes on material English articles, and compares this instructional design with the traditional instruction. Design of experimental research consisting of group experiments and controls. The experimental group $(\mathrm{N}=23)$ is subject to flipped instruction, where learning content is provided outside of class time through electronic means of LINE and class time is used for activities. In the control group, students $(\mathrm{N}=23)$ are taught in traditional methods, where learning is delivered during classes and additional exercises are given outside class time.The subect of the study was eight grade student of Madrasah Tsanawiyah Asy'ariyah.Pre test and post test are given to students in advance and at the end of material to know the impact of two teaching methods in English articles. Findings show that students in flipped classroom do English articles better in the post-test than in the pre- test.The pre and post test values of the experimental group showed that the significance value ( 2 -tailed) was 0,000 (p <0.05). So the results of the initial test and final test underwent significant changes. The result from the flipped and traditional approaches is very significant. Most students who flipped generally have a good perception of the flipped class. With This research, it is hoped that the teacher can apply this strategy in different material. For student must be more understand about English articles.
\end{abstract}

Key words: English articles, flipped classroom, LINE

\section{Introduction}

To follow the era 4.0 that is so rapid, researcher In recent years, found a strategy that can utilize social media as a means of delivering second language learning material (hereafter L2) is a flipped classroom example (ZaferUnal\&AslihanUnal 20017, Yi-Bin Li, Wen-ZhiZheng\& Fan Yang 2017, Biwen lee 2017) refer to (Bergmann \&Sams 2012, Herreid\& Schiller 2013, Jungić, Kaur, Mulholland \&Xin 2015). Those flipped classrooms are teaching facilities that are used by students to learn new content through technology as they are outside the classroom. As mentioned by learning that is more practical than focusing on a didactic application. Opportunities in flipped classroom eventually empower students to grow and expand the potential of their target language. As reported by Attaran and Zainuddin (2016), flipped classroom are excited rather than traditional ones. Such views have also been supported by other researcher such as (Davies, Dean \& Ball 2013).

The application of the flipped learning design is different from the conventional version of teaching. In the old teaching pattern, students usually learn English from class activities with various explanations and exercises given by 
their teacher. As a result, this causes the class to be more teacher-centered, but under the flipped classroom conditions learners have more flexible learning activities outside the classroom through electronic resources, so they can take the opportunity to learn English outside the classroom in a more flexible way. Therefore, in the model of flipped classroom the teaching- learning process is more student-centered. Previous researcher have examined this strategy there are collocation material from (Suranakkarin, 2017) and (Arifani, 2019), English Idioms (hsieh dkk, 2017) another that, this strategy can also examined in skill writing (Said Ahmed, 2017), and speaking skills (Sarasyifa, 2018). Because the absence of researching for several article materials uses this strategy the researcher will examine the article material using flipped learning trough LINE.

Fry, Kress \& Fountoukidis, (1993) state that English articles (a, an, and the) are considered as the most frequent words in English. Furthermore, Master (2002, p. 2) also states that the article is shown to be the most frequent words in the English language and the fifth most frequent word. In addition, Berry (1993) states that almost eight and a half percent of English texts contain language and text. Depending on these statistics, it is clear that English articles are an important part of English. Kim and Lakshmana (2007, p. 103) also say that the English article system, in general, is known to cause learning difficulties for English students as a Second Language (L2). Furthermore, Dulay, Burth and Krashen (1982, p. 165) state that L1 language students, who do not have other languages to transfer, have been found to make many mistakes in the article. Meanwhile, in real life, there are still many students who are still confused using parts of grammar such as using articles. They often make some mistakes when they use articles in sentences such as "a, an, or the" article. As this study is formulated to gauge the effect of using flipped model with LINE in English articles, the following question is posed: Is there any significant differences before and after applying the teaching process of Flipped Classroom through LINE to students?

\section{Literature Review}

\section{Flipped Learning through LINE}

Flipped learning is not a new research idea, but the development of increasingly sophisticated digital technology allows students everywhere to receive information and contact their peers, so Flipped learning is emphasized again (Bin li, Zheng \& Yang, 2017). This is in accordance with Vygotsky's theory where learning carried out with group discussions is able to build the ability of students to communicate and express ideas or ideas with friends or teachers, so as to be able to build their knowledge through interaction in learning. There were some previous researcher who claimed that flipped classroom was indeed effective (Ahmed, 2017; Chen Sieh at al, 2017; Haghighi, 2018; Suranakarin, 2018; Sarasyifa, 2018; Arifani, 2019; Faridh, Sukestiyarno \& Mariani, 2019) one of which mentioned by arifani, 2019 which discussed flipped classroom via WhatsApp in the collocation material where this strategy is indeed very effective because the result is that the group learning process is better than the individual. Apart from him, (Chen Sieh at all, 2017) also confirmed that this strategy was very effective; they applied this strategy in learning English idiom using the LINE module. Before their research (Sarasyifa, 2018) also included some advantages in the Flipped learning, namely: a) more interactive in the discussion; b.) increasing student involvement in the material; c.) increasing interaction between students and teachers. So that their interactions in Flipped learning can be facilitated through Social interactivity is from a mobile application where features can help students to interact with large amounts of exposure, to exchange various types of content, and to collaborate with classmates and colleagues (Dehghan, Rezvani, \& Fazeli, 2017). In the last years some researcher have focused on models such as the flipped classroom (suranakarin, 2018; Arifani, 2019) they examined the flipped classroom in collocation material which is indeed the result is significant in its outcome or process. Then there are more than (Sarasyifa, 2018) who examine Flipped classroom in speaking skills also show very significant results. Because there is no flipped classroom model in learning articles, therefore researcher wants to know this English Articles. Some researcher was support this statement. Arabski (1979) at that time carried out detailed research on the use of articles in Polish ESL learners, in the results of written texts which found that Polish ESL learners from English majors at the University of Silesia had great difficulty in using appropriate articles. Huong (2005) also found in his sample written by ESL Vietnamese students that the writing of Articles is still in the highest presentation of errors. After the understanding Zabor explained above often depends on the context, for example nouns in English can be counted and cannot be counted: "I have one hair in my soup" ( noun hair can be counted) or "I have black hair " ( noun hair countless).As a result, Zabor argues that "articles are one of the most difficult structural elements for second language learners (L2)" (Zabor, 2011)..According to (Sholihatun , 2017) that articles are very important targets to detect errors because of the most frequent errors in learning English. It can be seen in the results of his research showing that junior high school students in Palembang also still experience errors in the application of English Articles in descriptive texts where they still often experience omission in its application. Then (Abid Tayab, 2016) tried to measure English articles to be learned by Arabs, from their results they had difficulties in applying them because in Arabic it had to emphasize contrastive analysis. But it also (Kyoung Sim \& Kim, 2017) tried to examine the use of teaching English article Bundle Lexical followed by high- low-intermediate and intermediate English as a second language students where teaching is still traditional, participant asked to make sentences that have been prepared bundle lexical and still many participants experienced errors that were the faults in applying the English articles. 
As already discussed, ESL students still have difficulty applying English Articles in their writing. Previous researcher had not used Flipped learning in their research but (Gillient \& Lew, 2018) used e-learning in English Articles learning, namely a binary scheme and a teacher scheme with effective results. But in this thesis research will apply flipped learning through LINE in learning English Articles because researcher want to ensure this strategy is more accessible to students or not and knows the process.

\section{Scientific Approach}

Active learning strategies are learning activities that are centered on students that require students to 'do something' and think and reflect about what they do (Bonwell \& Eison, 1991; Misseyanni, Lytras,Papadopoulou, \& Marouli, \& 2018). A number of student-centered theories and learning methods that are used to guide the design of activities in the classroom including peer tutoring (peer assistance), cooperative learning, problem based learning, learning collaborative (Bishop \& Verleger, 2013). In this way, flipping learning "represents a unique combination of learning theories that were once considered inappropriate. Active problem-based learning activities built on constructivist ideology and instructional teaching derived from direct teaching methods based on behavioral principles "(Bishop \& Verleger, p. 1).

Learning English articles by applying the Flipped Classroom strategy with a scientific approach is expected to actively empower students in their potential, to construct their knowledge, then the knowledge that students already have can be applied in solving other English language problems. Henceforth students are expected to be able to work, or entrepreneurship with the knowledge they already have.

\section{Lecturing Method}

Suparta and Noer Aly (2003: 170) define lecture is every presentation of information orally, both formal and lasts for 45 minutes as well as the informal and only takes 5 minutes. In relation to learning, lecture is a teaching method in the form of narrative material verbal lessons. Karo (1984: 8) calls it the lecturing method or telling- method is an oral method of presentation of learning material done by someone (teacher) to another person (students) to achieve teaching objectives. The lecture method is the oldest, most common method used in various situations. Besides being used most often too often criticized. They argue that the lecture method is considered not appropriate for use in the world of education and teaching because contrary to the principle of learning that students must be active. However, that does not mean lecture is a method obsolete, in the sense that it cannot be used anymore. Lecture method no can be judged as good or bad, but must be based on purpose its use.

\section{Methods}

In this design, the researcher will use at experimental design. Jack R Fraenkel \& Norman E Wallen, (2008) state that the best way to do this is to test hypotheses about relationship between variables using experimental design. This research can be classified as quantitative design. Quasi-experimental designs with unequal control groups and pre-test / post- test designs will be conducted. The purpose of this study was to find a significant difference between mastery of English article EFL students who were taught using LINE-based flipped instructions with English article activities with instruction in traditional teaching models. The random sampling method was carried out carefully to order the experimental group. Furthermore, both cohorts were given with pre-test followed by six weeks of treatment and a posttest. Data in this study using random sampling. The researcher selected random sample from the students, surveyed them and drew conclusions on the English articles test results or respond based on feedback from the group. The researcher divide into two part experimental blocks and control block

\section{Participants}

The population consists of all EFL eighth grade students from Tajungsari Madrasah Tsanawiyah (MTs), Tlogowungu, Pati, located in Central Java, Indonesia. This school, consisting of two classes in the 2018-2019 academic yearTo draw two homogeneous classes where students have the same mastery of English and the environment, confirmation and clarification of English teachers is also made. Based on the above considerations, two classes in a row of 23 students (13 men and 12 women) were associated as experimental groups of class VIII A and 23 students (12 men and 15 women) from class VIII B were labeled as a control group.

In this design, the researcher will use at experimental design. Jack R Fraenkel \& Norman E Wallen, (2008) state that the best way to do this is to test hypotheses about relationship between variables using experimental design. This research can be classified as quantitative design. Quasi-experimental designs with unequal control groups and pre- test / posttest designs will be conducted. The purpose of this study was to find a significant difference between mastery of English article EFL students who were taught using LINE-based flipped instructions with English article activities with instruction in traditional teaching models. The random sampling method was carried out carefully to order the experimental group. Furthermore, both cohorts were given with pre-test followed by six weeks of treatment and a posttest. Before conducting the test, the researcher first observes at the school to ascertain whether there is more than one class in the school, to be used as a control and experiment group. After that the researcher looked at the results of grades in semester one as an evaluation material in learning English articles. The English articles test was given twice, in the pre-test and the post-test to answer the key point of research question "Is there any significant differences before and after applying the teaching process of Flipped Classroom through LINE to students class VIII A \& B of MTs Asy'ariyah?" 
The pre-test was administered before giving the treatment to know the knowladge English articles of the students. Then, the post- test was administered to check whether the flipped classroom model can enhance or not toward students' English articles. The instrument of the English articles test in this research adopted from the Huong (2005) and Gillian (2017).

After conducting the pre and post test, the next step is to analyze the data. In conducting research, it is necessary to analyze data to interpret data obtained from the field. Data analysis was performed to answer the research problem with data obtained through pre and post test. The researcher analyzed the data using independent sample t-tests. Because the sample is small and the groups are independent, $t$-tests for independent samples are conducted to determine whether there are differences between the experimental and control groups.

The researcher used SPSS version 16.0 to calculate statistics on student knowledge in the use of English articles. This study was conducted to determine the effect of treatment whether it is significant or not using the flipped classroom method through LINE. Assumptions forindependent t-tests where: (1) Independence: Observations in each sample must be independent (they do not influence each other); (2) Normal Distribution: Both populations must be normally distributed. This research is included in parametric research which is divided into two types of data; ratio and interval The data of this study are ratios because zero has a value or absolute zero. when the data ratio, the data is definitely homogeneous and the distribution is normal. Finally, (3) Variant Homogeneity: The two populations must have the equal variant (the degree which the distribution are spread out is approximately equal).

\section{Findings}

Result of normality the df were 23 , its means less than 50 so the researcher must see sigificance in shapiroWillk. The result of shapiro-Willk sample testfor equality of varience showed tha the Sig in experiment group is 0,214 and for control group is 0,224 , which means that the data was normal because the Sig both of group were higher than the level of the significance $(>0.05)$. So it could be stated that to analyzed the independent variable by using parametric

Result of homogenity the df were 23 , its means less than 50 so the researcher must see sigificance in shapiro-Willk. The result of shapiro-Willk sample testfor equality of varience showed tha the Sig in experiment group is 0,214 and for control group is 0,224, which means that the data was normal because the Sig both of group were higher than the level of thesignificance (>0.05). So it could be stated that to analyzed the independent variable by using parametric

The purpose of this study is to measure the effects of flipped classroom on students' English articles knowledge and to compare whether flipped instruction is significantly more effective in teaching English articles than traditional teaching. Findings show that students in flipped classroom do English articles better in the post- test than in the pre-test. Also, the results obtained from the post-test revealed that the effects of the flipped and traditional classes differed significantly. To see the comparison, the findings are disclosed and described as follows.

Result both of test the pre and post test values of the experimental group showed that the significance value (2-tailed) was $0,000(\mathrm{p}<0.05)$. So the results of the initial test and final test underwent significant changes. Simply, the students involved in the flipped class produce the target English articles in the post-test easier than they did in the pre-test.

This study aims to compare whether flipped instruction is more effective than traditional instruction for teaching English articles. It is not surprising that students performed better on their post-tests than on their pre-tests. In fact, the posttest score of instruction flipped mean higher than the mean pre-test score, indicating that students actually learned as a result of flipped instruction used in thisstudy. It also shows that before the semester starts, most students do not know English articles that are taught in class. The overall results show that the learning outcomes of English articles students increased significantly after being in the flipped class.

The key to the success of flipped instruction is whether students actually do preparatory work outside the classroom. If not, the researcher cannot involve them at an advanced level in the classroom. Many strategies have been suggested for researcher to be used to ensure that work is done November \& Mull, (2012 ). In this study researcher were able to overcome challenges and motivate students to do work because instructional design is rooted in output material, that is, online writing .In order to successfully create results, students must absorbing previous learning material. In addition, researcher provide timely feedback, so students know that they are being monitored and their progress is evaluated, beyond the formative feedback given during each assignment. In addition, activities in the classroom require special knowledge and are easy for researcher to detect and intervene students who are not ready. As stated by $\mathrm{Chen} \mathrm{Hsieh}, \mathrm{Wu}$ and Marek (2016), teachers can help students overcome challenges by providing timely feedback, allowing students to realize that they are being facilitated and that their performance is being evaluated.

However, the likelihood of a flipped class success largely depends on the instructor's ability to maximize the benefits of the other three principles. Simply put, the flexibility of online self-study, student-centered approaches and the right teaching content may not be enough to make a flipped class be the most successful without the help of an instructor who acts as a facilitator. Sarawagi (2014) which asserts that in addition to acting as a lecturer, teachers who act as facilitators are beneficial in class, increasing active learning and learning beliefs among students. From this explanation, it can be explained that the teacher can act as an effective facilitator in helping students understand the learning of English articles.

This flipped classroom can have a beneficial effect on learning carried out by students of Mts.asy'ariyah. This finding is in accordance with the findings of Hung (2015) in research on flipped instruction. Hung proposes that structured learning material based on an flipped learning approach produces a positive impact on how students understand the 
learning environment and how they understand the learning process. However, it seems difficult to determine how strong the effects of flipped classes are and whether they directly affect student learning outcomes. In addition, several previous studies ( Marrs \& Novak 2004) showed that additional learning material, such as websites or related electronic resources, had a positive influence on the active learning environment. With the introduction of technology, Sarasyifa, (2018) suggested that learning materials can be integrated based on activities in the classroom and the learning environment outside the classroom of students.

Although the score of the post test of the best class shows that it is very significant, but from the reverse process is still experiencing a shortage because students still have not implemented interaction based learning and timing, because in this flipped process Very attached to it, so that both things are instrumental.

Referring to the first thing that is interaction in this process of flipped learning students are still adapting to it, seen from their interactions in the group, which they still merely listen to without having to treat the material. As soon as it was seen students who were actively interacting, they had a superior answer from those who were passive. This is indeed a very influential interaction in learning. It is said by Tayjasanant and Suraratdecha (2016), stating that interactive learning largely supports learners in the learning of language processes.

Furthermore, referring to the second thing is time, where the learning upside down is very need time outside the classroom, so those who are not accustomed to be difficult to set the time, proved with students who when already time their discussion there Need or activity. And also the time it takes to adapt to a new learning environment (flipped approach) is not enough. Because in this researchstudents are faced with a flipped approach of only one week that may not be enough for them to adapt to this new learning mode. So researcher these two things that affect the students in the learning process lacks flipped classroom.

Therefore, these results support the findings of previous researcher by Arifani, (2019) Sarasyifa, (2018) and Hsieh at al. (2017) who flipped class models influencing student learning especially in the EFL context. However, this study is different from Arifani , (2019) who examined the effect of group work in the flipped class material Collocation model using Whats App. Where this is specific in English Articles material and use LINE. Although, it is the implementation of the experiment is the same as being done for six meetings. The previous research was previously conducted by Hsieh at al. (2017) who used the same LINE in an flipped class model but to improve oral and written idioms. Experimental exposed to classroom instruction flipped material conveyed in out grade and time in the classroom is only conducting. The controlled class is taught by a traditional method model in which lessons are delivered during class and additional exercises are given outside of class time. In line with this research mainly in the procedure but has several modifications to the application of the flipped model and also the material is different. Previous research conducted by Gillient \& Lew, (2017). They find problems in learning , English articles because students are often confused in using them so they use a number of e-learning strategies applied in schools. Because the use of e-learning is limited in schools, in this study the researcher wanted to maximize activities outside the classroom as well, by using a flipped class model.

In conclusion, students involved in flipped learning greatly benefit from learning English articles through the reverse learning model. The fact that the effects of classrooms are inverted compared to traditional classrooms is very significant. And it is not only the learning design that makes students pay attention but also the interaction of researcher which makes students feel cared for.

\section{Conclusion}

Current research investigates the effects of flipped learning model on material English article and compares whether students taught by flipping method are more successful in learning English article compared to traditional methods. Overall, the findings show that the students ' English article learning results are significantly improved after the class implementation is flipped. The results also showed that the effect between the flipped and traditional classrooms resulted in a significant difference. As stated by Marek and Wu (2012), the LINE Smartphone app helps facilitatecommunicative interactions with individuals outside of class and allows instructors to engage students in interactive classroom activities. Chen Hsieh, Wu, and Marek (2016) also stated that little academic research has used LINE as a variable to help improve student learning about certain English language skills. Thus, in further experimental grade research, instructors who wish to flip classes are advised to use LINE as an online learning platform to improve students ' English articles

\section{References}

Adams, P.D. (1993). Basic Writing Reconsidered. Journal of Basic Writing, 12 (1), 24.

Andriyani, D. (2007). Teori Belajar dan Pembelajaran. Jakarta: Universitas Terbuka.

Armstrong, C., \& Lonsdale, R. (1998). The Publishing of Electronic Scholarly Monographs and Textbooks. University of Wales Aberystwyth.

Arikunto, S. (2013). Dasar-Dasar Evaluasi Pendidikan. Bumi Aksara: Jakarta.

Arkun, S., \& Akkoyunlu, B. (2008). A Study on the Development Process of a Multimedia Learning Environment According to the ADDIE Model and Students ${ }^{\text {ee }}$ Opinion of the Multimedia Learning Environment. Interactive Educational Multimedia, 17, 4.

Ary, J., Jacobs, L.C. \& Razavieh Asghar. (1990). Introduction to Research in Education. USA: Saunders College Publishing.

Branch, R. M. (2009). Instructional Design: The ADDIE Approach. Springer: New York. 
Budi, T.P. (2006). SPSS 13.0 Terapan: Riset Statistik Paramterik. Yogyakarta: Andy Offset.

Borchers, J.O. (1999). Electronics Books: Definition, Genres, Interaction Design Patterns. 2.

Brown, D.H. (2007). Teaching by Principles: An Interactive Approach to Language Pedagogy. New York: Pearson Longman.

Balmford, C. (1999). Getting the Structure Right: Process, Paradigm, and Percistence (Part 2). Clarity, $43,14$.

Bergman, R. E., \& Moore, T. V. (1990). Managing Interactive Video/Multimedia Projects. Englewood Cliffs, New Jersey: Educational Technology Publications.

Bonime, A. \& Lonsdale, R. (1998). Writing for New Media. The Essential Guide to Writing for Interactive Media, CDROMs and the Web. John Wiley \& Sons: New York.

Castronova, J. A. (2000). Discovery Learning for the 21st Century: What is it and how does it compares to traditional learning in effectiveness in the 21st Century?

Cahyo, D.N. (2015). Pengembangan Media Pembelajaran Interaktif Komunikatif dan Inovatif Untuk Pembelajaran Gerbang Dasar Digital Kelas X SMK Muhammadiyah Prambanan. Skripsi: Universitas Negeri Yogyakarta.

Choi, J., Lee, Y., \& Kim, K. (2014). An HTML5-based Interactive E-book Reader. International Journal of Software Engineering and Its Application, 8 (2), 68.

Coffin, C., Curry, M. J., Goodman, S., Hewings, A., Lillis, T. M., Swann, J. (2003). Teaching Academic Writing. London: Routledge.

Darcey, L., \& Conder, S. (2009). Android Wireless Application Development. USA:Addison-Wesley Professional.

Dick, W., Carey, L., \& Carey, J. O. (2001). The Systematic Design of Instruction (Fifth Edition). New York: Longman. Desy, J. (1976). Reasoned Writing for Basic Students: A Course Design. Journal of Basic Writing, 1 (2), 6-9.

Flowers, B. S. (1981). Madman, Architect, Carpenter, Judge: Roles and Writing Process. Language Arts, 58 (7), 834835.

Gall, M. D., Gall, J. P., \& Borg, W. R. (2003). Educational Research An Introduction (Seventh Edition). USA: Pearson Education.

Gebhard, J. G. (1996). Teaching English as a Foreign or Second Language. A Teacher Self-development and Methodology Guide. Michigan: The University of Michigan Press.

Gilyard, K. (2000). Basic Writing, Cost, Effectiveness, and Ideology. Journal of Basic Writing, 19 (1), 37.

Gustafson, K. L., \& Branch, R. M. (2002). Survey of Instructional Developments Models (Fourth Edition). New York: ERIC Clearinghouse on Information \& Technology.

Hawkins, D. (2000). Electronic Books: A Major Publishing Revolution, Part 1, Online, 15-28.

Haghighatgoo, O. (2016). Production of Game Content for Mobile Phones based on Android Operating System. International Journal of Computer Science and Mobile Computing, 5 (3), 141.

Hanafi, H. F., \& Samsudin, K. (2012). Mobile Learning Environment System (MLES): The Case of Android-based

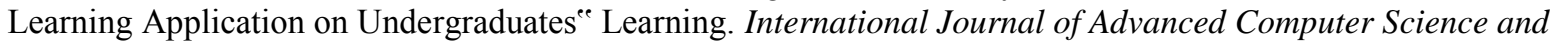
Applications, 3 (3), 1-2.

Haque, N. (2014). A Brief Study on Need Analysis. Express, an International Journal of Multi Disciplinary Research, 1 (1), 2 .

Harrington, S., \& Kassner, L.A. (1998). The Dilemma that still Counts: Basic Writing at a Political Cross-Roads. Journal of Basic Writing, 17 (2), 6-11.

Horne, L.K. (2012). Apps: A Practical Approach to Trade and Co-Financed Book Apps. Publishing Research Quarterly, Springer, 28, (1), 17-18.

Holla, S., \& Katti, M. M. (2012). Android based Mobile Application Development and its Security. International Journal of Computer Trends and Technology, 3 (3), 486.

Hoog, R. de, Jong, T. de, \& Vries, F. de. Constraint-Driven Software Design: An Escape From the Waterfall Model. Performance Improvement Quarterly, 7 (3), 48-63.

Horner, Bruce. (1994). “Mapping Errors and Expectations for Basic Writing: From the „Frontier Field"e to „Border Country". English Educational, 26 (1), 1-2.

Hutchinson, T. \& Waters A. (1987). English for Specific Purposes: a Learning-Centred Approach. Musselburgh: Cambridge University Press.

Isman, A. (2011). Instructional Design in Education: New Model. The Turkish Online Journal of Educational

Technology, 10 (1), 136.

Kassner, L.A. (1999). Just Writing, Basically: Basic Writers on Basic Writing. Journal of Basic Writing, 18 (2), $72-75$.

Kibona, L., \& Rugina, J. M. (2015). A Review on the Impact of Smartphone on Academic Performance of Students in

Higher Learning Institution in Tanzania. Journal of Multidisciplinary Engineering Science and Technology, 2 (4), 673.

Kovrig, A. (2005). IcoFX-About us. Accessed January 2017 at http://icofx.

ro/contact.html.

Lee, K. B., \& Salman, R. (2012). The Design and Development of Mobile Collaborative Learning Application Using Android. Journal of Information Technology and Application in Education, 1 (1), 5.

Lee, W. M. (2011). Beginning Android Application Development. Indiana: Wiley Publishing. 
Lu, M. Z., \& Horner, B. (2000). Expectations, Interpretations and Contributions of Basic Writing. Journal of Basic Writing, $19(1), 43$.

Lucantoni, P. (2002). Professional Development for Teachers: Teaching and Assessing Skills in English as a Second Language. Cambridge: Cambridge University Press.

McGriff, S. J. (2000). Instructional System Design (ISD): Using the ADDIE Model. Instructional Systems, College of Education, Penn State University.

Miekley, J. (2005). ESL Textbook Evaluation Checklist. The Reading Matrix, 5 (2), 4-5.

Molenda, M. (2004). Education and Technology: an Encyclopedia. USA: Library of Congress Cataloging-in-Publication Data.

Mukharomah, L. (2015). The Use of Discovery Learning Model to Improve Students' Descriptive Text Writing. Thesis: Walisongo State Islamic University.

Muruganantham, G. (2015). Developing of E-Content Package by Using ADDIE Model. International Journal of Applied Research, 1 (3), 53.

Nardo, T.B., \& Hufana, E.R. (2014). Development and Evaluation of Modules in Technical Writing. American Journal of Educational Research, 2 (6), 341-350.

Nordquist, R. (2015). Basic Writing. Accessed January 2017 at http://grammar.

about.com/od/ab/g/Basic-Writing-term.htm

Nurkancana, W. (1992). Evaluasi Hasil Belajar. Surabaya: Usaha Nasional.

Oshima, A., \& Hogue, A. (1998). Writing Academic English (Third Editon). New York: Pearson Longman.

Otte, G., \& Mlynarczyk, R. W. (2010). Basic Writing. Indiana: Parlor Press.

The College Years. (2012). Examsmanship and the Liberal Arts. An Epistemological Inquiry. BSC: Harvard University. Tyner, T.E. (2008). Writing Voyage. A Process Approach to Writing. Thomson Wadsworth: Boston.

Passerini, K. \& Granger, M.J. (2001). A Developmental Model for Distance Learning Using the Internet. Computers and Education, 34, (1), 4-5.

Perry, W.G. (1963). Examsmanship and the Liberal Arts. A Study in Educational Epistemology. Examining in Harvard College: a Collection of Essays by Members of the Harvard Faculty, Cambridge: Harvard University.

Riyanto, Y. (2009). Paradigma Baru Pembelajaran. Jakarta: Prenada Media.

Rabideau, M. P. S., \& Brossell, G. (1995). Finding Basic Writingee s Place. Journal of Basic Writing, 14 (1), 22.

Reid, J. M. (1996). Basic Writing. USA: Prentice Hall.

Rouse, M. (2015). Photoshop. Accessed January 2017 at http://whatis.techtarget

.com/definition/Photoshop

Sailah, S., Kunaefi, D. T., Soetanto, H., Utama, I. M.S., Mursid, Endrotomo, Dewajani, S., Arifin S., Sugiharto L.,

Djajanto, L., Jumhur, Herlina, L., Hosea E., Tutupoho, R. R., Evawany, Udin, N. M. (2014). Buku Kurikulum Pendidikan Tinggi.

Samal, S., \& Jena, S. P. (2014). Research on the Development of a New Shop Application Using Android. International Journal of Advanced Computer Research, 4 (1), 236.

Sarrab, M., Elgamel, L., \& Aldabbas, H. (2012). Mobile Learning (M-Learning) and Educational Environments.

International Journal of Distributed and Parallel Systems, 3 (4), 32.

Seels, B., \& Glasgow, Z. (1997). Making Instructional Design Decisions (Second Edition). USA:Pearson.

Shiratuddin, N., \& Hassan, S. (2003). A Usability Study for Promoting eContent in Higher Education. Educational

Technology \& Society, 6 (4), 112.

Sharma, R. (2016). What is Bluestacks App Player? Is it Safe to Use? Accessed January 2017 at

http://allusefulinfo.com/what-is-bluestacks-app-player-is-it-safe-to-use/

Shaughnessy, M. P. (1976). Diving in: Introduction to Basic Writing. College Composition and Communication, 27 (3), 236.

Shaughnessy, M. (1976). Statement on Criteria for Writing Proficiency. Journal of Basic Writing, 3 (1), 115-119.

Sivakumar, R. (2015). Android App in Teaching English. Journal of Contemporary Educational Research and

Innovations, 5 (5), 215.

Sugiyono. (2014). Metode Penelitian Kombinasi (Mixed Methods). Bandung: Alfabeta.

Sukardi, H.M. (2008). Evaluasi Pendidikan \& Operasionalnya. Jakarta: Bumi Aksara.

TEAL (Teaching Excellence in Adult Literacy). (2010). Student-Centred Learning. TEAL Center Fact Sheet No. 6:

Student-Centred Learning, 1.

The Herridge Group. (2004). The Use of Traditional Instructional Systems Design Models for eLearning. Uehling, K.S. (2003). Creating a Statement of Guidelines and Goals for Boise State University ${ }^{\text {ee }}$ Basic Writing Course: Content and Development. Journal of Basic Writing, 22 (1), 23-27.

Ulwan, A. N. (2015). Pengembangan Aplikasi Ada Apa Dengan Kimia Berbasis Android Sebagai Sumber Belajar

Mandiri Pada Materi Termokimia Kelas XI SMA/MA. Skripsi: Universitas Negeri Yogyakarta.

Welty, G. (2007). The „Design "e Phase of the ADDIE Model. Journal of GXP Compliance, 11 (4), 41.

Weaver, B. (1985). Bibliography of Writing Textbooks. 
West, J. (2008). IcoFX Creates and Edits Icons for Free. Accessed January 2017 at http://lifehacker.com/5079953/icofxcreates-and-edits-icons-for-free

Wicaksono, B.P. (2015). Pengembangan Media Pembelajaran Kendali Terpogram Berbasis Android Pada Mata

Pelajaran Merakit Sistem Kendali Mikrokontroller di SMK Negeri 2 Depok. Skripsi: Universitas Negeri Yogyakarta.

Wolber, D., Abelson H., Spertus., E., \& Looney L. (2015). App Inventor 2: Create your Own Android Apps. USA: $\mathrm{O}^{\text {ee Reilly. }}$ 